\title{
ANALYSIS OF DAMAGED LAND CHANGES IN KLAIPEDA COUNTY OF LITHUANIA
}

\author{
Giedrè Ivavičiūtè \\ Aleksandras Stulginskis University, Lithuania \\ Kaunas Forestry and Environmental Engineering University of Applied Sciences, Lithuania \\ Klaipeda State University of Applied Sciences, Lithuania \\ ivavice@gmail.com
}

\begin{abstract}
The article presents the analysis of the current situation of the damaged land in Klaipeda County. The study found that the number of affected areas in the county -266 . Because the damaged areas consist of mineral quarries and territories occupied by dumps, the article contains the description and condition of these areas. It was found that mostly sand deposits (60) predominate in Klaipeda County, of which only 8 are used.

The smallest number of the deposits - the salt deposits (2). The mainly used deposits in the county are sand and gravel deposits - 29, unused - sand deposits (52).

The Klaipeda municipal waste management region comprises 7 municipalities, 39 old landfills and dumps were shut down. At present, 1 regional non-hazardous waste landfill has been arranged.

In Klaipeda County, in 2015, damaged land occupied 2,391.06 hectares and amounted to 0.46 percent of the county's area. During the period between the years 2005 and 2015 the damaged land area in Klaipeda County increased by 130.25 hectares.

The analysis of the damaged land by type of ownership showed that the damaged land areas in private land increased by 75.54 hectares or 58.52 percent. In the state land, the damaged land area decreased by 442.35 hectares or 20.04 percent.
\end{abstract}

Key words: damaged land, landfills, mineral quarries, rehabilitation.

\section{Introduction}

Article relevance. Damaged land management becomes more and more important, because due to the improperly managed and uncontrolled landfills as well as due to the damage of not rehabilitated quarries, the threat is being posed to human health and the environment. Landscape ecological stability and unity are life survival necessities.

Natural landscape is decreasing and losing the ecological and aesthetic value every year. The landscape is polluted by abandoned residential and farm buildings, reinforced concrete electric poles, illegal waste landfills, cut down forest areas, not rehabilitated quarries, innings, wasteland and others.

In the Journal of the National Land Service "Land Fund of the Republic of Lithuania by January 1, 2015" the damaged land is described in the following way: operating and depleted mineral quarries, peat bogs and landfill areas (Nacionaline, 2005 - 2015).

According to the principal purpose of land use, the damaged land is classed as land used for other purposes.

Minerals are natural materials existing in the earth's crust that can be used for substantive production or other uses (Lietuvos, 2001).

Mineral quarrying has a significant impact on nature and social environment (Burger, 2008).

The Law on Land of the Republic of Lithuania Art. 21 Item 6 (Lietuvos, 2004) states that the land owners and other users, exploiting mineral resources, must preserve the fertile soil layer and rehabilitation of damaged land.
Natural and legal persons exploiting mineral deposits and peat bogs, engaged in geological prospecting, exploration, construction and other works related to the fertile soil layer infringement must start the rehabilitation of damaged agricultural land and forest areas into agricultural land and forest, and if it is technically impossible - into bodies of water (Lietuvos, 1995).

According to the Terrestrial Law (Lietuvos, 2001 b), mineral deposits' users in the first five years of the use of geothermal resources must accumulate the funds needed for land rehabilitation after mining and other necessary measures of environmental elements to implement the recovery; however, this provision is not always carried out.

According to Virginija Atkoceviciene and Vilma Sudoniene (Sudoniene \& Atkoceviciene, 2013), land owners and users, operating mineral quarries must comply with the requirements and regulations in order to preserve the fertile soil layer. In their research paper, the authors analyze the problems in the field of damaged land management and find that excavation, violation of accounting and control of the fertile layer of soil are not being carried out, which is necessary to regulate the rehabilitation of damaged lands.

Urbanization, the growth of population and generated waste in all parts of the world cause for concern and promote a sustainable and effective waste management system (Sumathi, Natesan, \& Sarkar, 2008).

The Waste Management Law of the Republic of Lithuania (Lietuvos, 2002) provides that the landfill 
is a waste disposal facility for the deposit of the waste onto or into land (i.e. underground). The landfill is assigned to a group of sources of pollution that pose a potential threat to groundwater users and other environmental objects.

15 waste disposal methods are foreseen in the European Parliament and Council Directive 2008/98/ EC (The European, 2008) and the above-mentioned Lithuanian Republic Waste Management Law. Waste placement in a landfill is the least desirable option, but still the dominant method of Lithuania.

As stated in the European Parliament and the Council Directive 1999/31/EC (The European, 1999), operating and the after closing landfills should be monitored and properly managed in order to reduce or counteract adverse effects on the environment and human health. It is necessary to protect natural resources, minimize the destruction of land, to stimulate waste prevention, recycling, and disposal of used materials and energy recovery.

In planning, managing and rehabilitating damaged land areas rational, innovative models should be selected that ensure the sustainable use of natural resources and ecosystem conservation and management.

The object of the research is Klaipeda County damaged land.

The aim of the research is to carry out the analysis of the Klaipeda County damaged land area during the period between the years 2005 and 2015 .

Goals of the research:

1. To describe the status quo of the damaged land in Klaipeda county.

2. To analyze and compare the damaged land change in Klaipeda county during the period between the years 2005 and 2015.

\section{Materials and Methods}

Comparative, analytical as well as statistical and logical analysis methods were used for the research.

The land fund statistics of the Republic of Lithuania (Nacionalinè žemès, 2005 - 2015), graphically depicted in figures, were used for the fulfilment of the research of the dameged land change in Klaipeda county for the years $2005-2015$.

The following scientific methods were used in this article: the European Union directives and Lithuanian legislation, analysis of scientific literature, existing positioning and measurement, comparative method, logical analysis, analytical, filing method, graphic and generalization methods.

The article analyzed and assessed the current state of the damaged land in the city of Klaipeda, i.e. the current state of the mineral deposits' areas and dumps was analyzed, the statistics were presented, which were systemized to structure and presented graphs.
The study provides the damaged land change analysis in Klaipeda County. The ten-year period, i.e. the period between the years 2005 and 2015, was selected for the determination of the change. For the fulfilment of the analysis, statistics of the land fund and other sources of the Republic of Lithuania (Geological Survey of Lithuania, the Ministry of Environment, county and regional waste management centers) were used. They were systematized, analyzed and expression of the percentage was calculated during the preparation of the research.

General plans and solutions, regional development plans, National Waste Management Plan, regional waste management plans were considered.

\section{Results and Discussion \\ Characterization of Klaipeda County.}

Klaipeda region is the only region in Lithuania having access to the sea. In the north, it is bordered by Latvia and to the south with the Kaliningrad region of Russian Federation. It consists of 7 municipalities, but only 4 of them have a coastline. Neringa of them, except for tourism and the length of coastline of 60.6 $\mathrm{km}$, can not fall within the scope of business activity, since it is located in a protected area. The coastline of the other three municipalities comes to the city of Klaipeda - $4.03 \mathrm{~km}$, Klaipeda district $-12.98 \mathrm{~km}$ and Palanga city $-20.48 \mathrm{~km}$. The territory from a northern pier in Klaipeda to the Lithuanian - Latvian border is $38.4 \mathrm{~km}$. 3 municipalities - Šilute, Kretinga and Skuodas have no access to the sea (Markevicius, 2015).

Klaipeda county covers an area of 522220.58 hectars that makes 7.99 percent of the entire territory of Lithuania. The agricultural lands make up 53.55 percent, forest area 26.89 percent, water bodies 10.43 percent, roads 1.63 percent, other land 3.07 percent of the Klaipeda county.

According to the functional priorities of the region's territories established in the general plan of the Republic of Lithuania (Lietuvos, 2002 a) Klaipeda County area falls into the first functional area, in which the recreational use priority of the national interest, maritime shipping, offshore fishing, institutionally organized conversion, conversion set at the level of laws and sustainable forestry become apparent. Klaipeda region functional priorities include a transport development, industrial development, sustainable agriculture and forestry.

\section{The current situation of damaged land in Klaipeda} county.

In Lithuania, the areas damaged by quarries, peat

bogs and landfills are several times larger than they should be according to the solid mineral mining open workings scale and the used mining technology. 


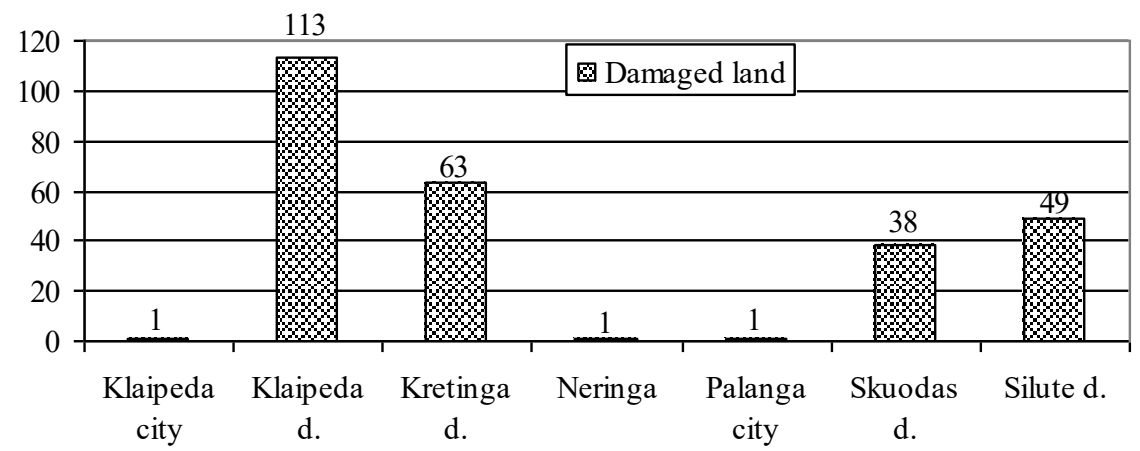

Figure 1. The number of damaged areas in Klaipeda County, in pieces (Compiled by the author of the article).

Almost half of the damaged areas of Klaipeda County are situated in Klaipeda district (113 pcs., or 42.80 percent). The town of Palanga, Klaipeda City and the Neringa municipality (Fig. 1) each has one such area. The number of damaged areas in the county -266 .

\section{Mineral deposits in Klaipeda County.}

Lithuania has 17 species of minerals used in the world and investigated at various detail levels (Lietuvos geologijos, 2017).

Many Lithuanian minerals are on the surface, they are well researched, easily accessible - mined by open quarries. Separate kinds of mineral resources within the country are distributed unevenly. Their deposits cover only 4.3 percent of Lithuanian territory. In various layers of the deposits, there are almost all kinds of the most important non-metallic minerals (Lietuvos žemès, 2017).

Extensive spread of Lithuanian territory is characterized by gravel and sand. These resources are mainly explored not only in Klaipeda, but also in Vilnius, Kaunas, Utena, Alytus and Taurage counties. Peat deposits are located throughout the country, including Klaipeda County. Also, rock salt is found in the county. Although clay is found almost everywhere in the country, these minerals are not found in Klaipeda County.

Sand deposits are located mainly in Klaipeda County -60 , of which only 8 deposits are used. The least are salts deposits -2 (Fig. 2).

It was found that, overall in the county, the most used are sand and gravel deposits - 29 (Fig. 3), not used - sand deposits (52).

Sand and gravel deposits are the most explored in detail ones. Currently, there are 24 peat deposits, which are preparatory explored. The prognostic 32 sand and 23 peat deposits were revealed (Fig. 4).

\section{Landfills.}

In 2006, Lithuania registered 850 municipal waste landfills (contaminated sites), of which 350 were used (Valstybès, 2013). Some of them were managed illegally, were not registered, with no permits. These landfills did not meet environmental and public health safety requirements, and their condition was poor.

Throughout Lithuania in 2009, there were about 680 small (up to 1 hectare) municipal waste landfills / dumps, about 120 medium-sized (1-5 hectare) landfills and 35 large (more than 5 hectares) landfills. In 2011, 11 regional landfills were arranged and adapted in Lithuania in accordance with the environmental requirements of the installation and use.

Klaipeda municipal waste management region comprises 7 municipalities, 39 old dumps were shut down in them, 1 regional non-hazardous waste landfill, 10 bulky waste collection sites, 7 green waste composting sites were arranged, a mechanical waste treatment plant was built, 10,000 individual composting containers were purchased.

At present, there is no complete and accurate information about the damaged areas in the country; therefore, it is necessary to systematically collect and analyze data. This should be a single institution which, according to the data available, should coordinate the land rehabilitation process.

\section{The damaged land change.}

In 2015, the damaged land in Klaipeda County covered 2391.06 hectares and amounted to 10.62 percent of all Lithuanian damaged lands and 0.46 percent of the entire county's area. In 2005, the analyzed land area of the county was 2,260.81 hectares or 9.14 percent of all country's damaged lands and 0.43 percent of the Klaipeda County area (Fig. 5). During the period between the years 2005 and 2014 the analyzed area declined each year (366.81 ha, or an average of 40.76 hectares per year) and was only $1,894.00$ hectares, but in 2015 the area picked up again. During the period between the years 2005 and 2015 the damaged land area in Klaipeda County increased by 130.25 hectares or 5.44 percent. It was influenced by the Klaipeda region landfill section III with the asbestos waste disposal area, the reserved 
area for construction and mineral production, for example, oil extraction area businesses and 4 new drilling equipment.

The largest area of the damaged land in 2015 was fixed in the Klaipeda region municipality, accounting for 15.32 percent of the entire Klaipeda County damaged land. During the period between the years 2005 and 2015 the damaged land area in Klaipeda region decreased by 51.73 hectares or 12.38 percent.

In 2005, the largest area of the damaged land was in Kretinga district. That area decreased by 142.49 hectares or 32.55 percent. There were no damaged lands in the Neringa municipality during the period between the years 2005 and 2010. In 2011 - 2013, the area of 1.85 ha was fixed, which in 2014 decreased to 0.93 hectares. In 2015, the damaged land area in Neringa municipality occupied 1.99 ha, i.e. the smallest area of all Klaipeda district municipalities.

Damaged land can be as in the land of private property, as well as in the state land. The damaged

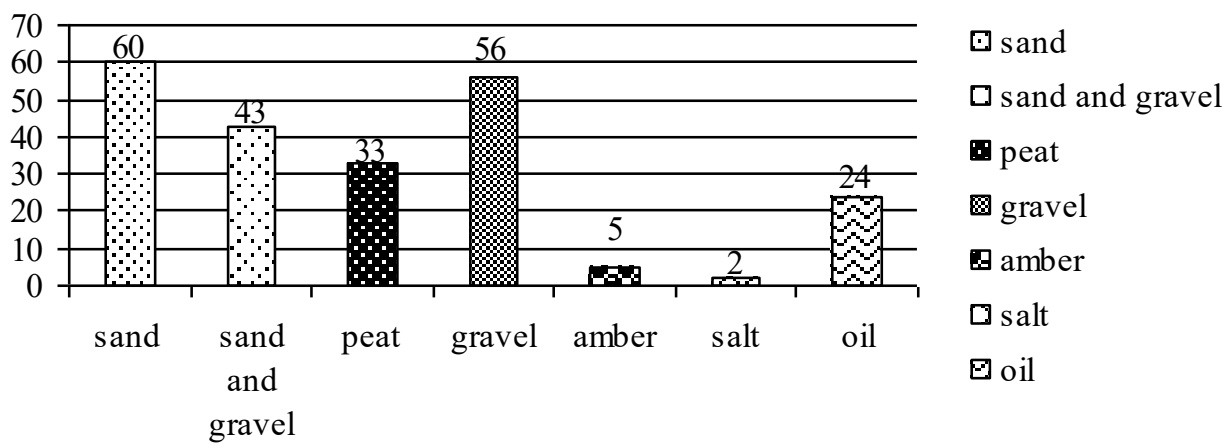

Figure 2. Mineral deposits in Klaipeda County (Compiled by the author of the article).

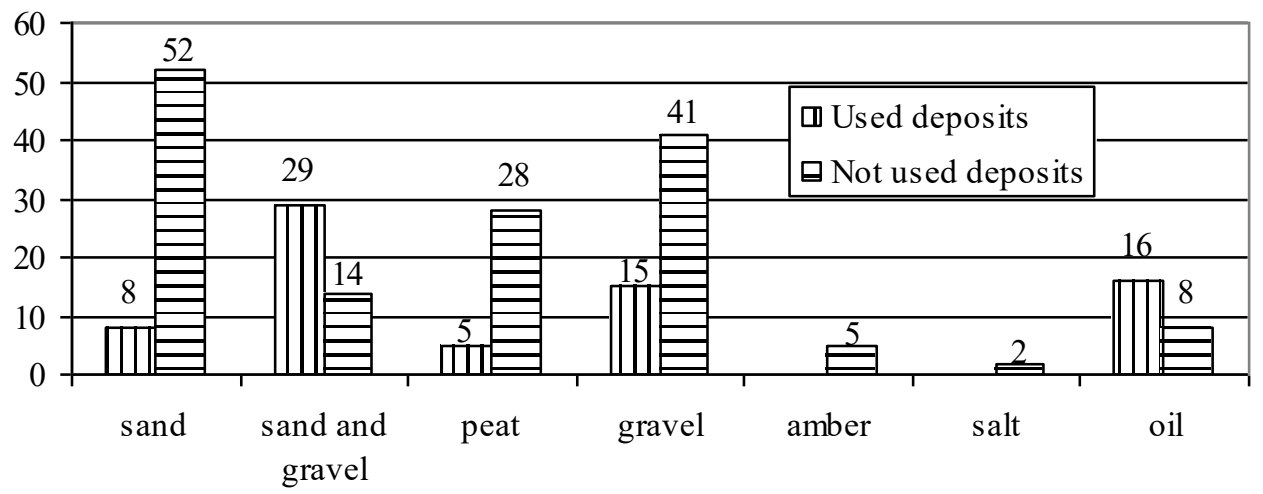

Figure 3. Condition of mineral deposits in Klaipeda County (Compiled by the author of the article).

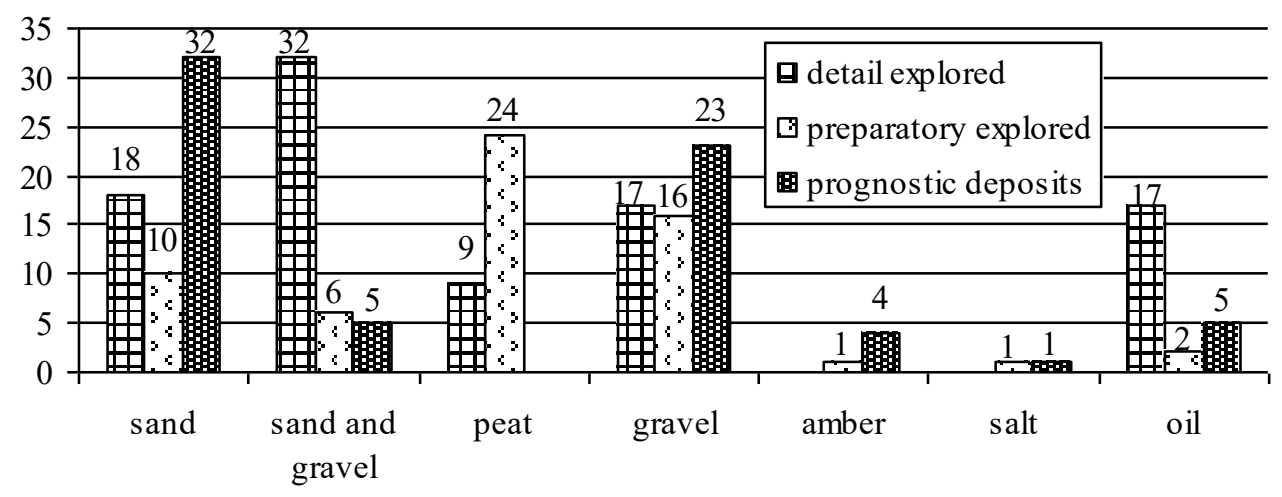

Figure 4. Deposits exploration in Klaipeda County (Compiled by the author of the article). 


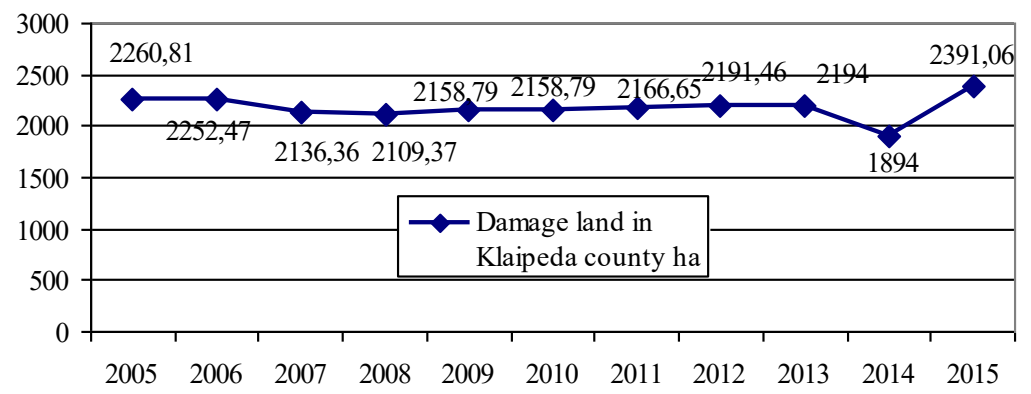

Figure 5. The damaged land change in Klaipeda County in ha during the years $2005-2015$

(Nacionaline, 2005 -2015), (Compiled by the author of the article).

land analysis by type of ownership showed that the damaged land area in private land increased by 75.54 hectares or 58.52 percent. State land area decreased by 442.35 hectares or 20.04 percent (Fig. 6).

\section{Analysis of the damaged land of Klaipeda region in} planning documents.

In Klaipeda region, the waste management is carried out in accordance with approved waste management plans and programs (Klaipedos, 2013). The main aim of the regional waste management plan is to harmonize the actions of municipalities in organizing municipal waste management systems and the creation of (common for several municipalities) waste recovery or disposal facilities (Ekokonsultacijos, 2014).

Looking for the sustainable development of the Klaipeda County waste management system (for the ten-year period), it has been foreseen in the general (master) plan (Valstybès, 2012) to collect, store, sort, and manage municipal waste in the regional landfill in Dumpiai (Klaipeda district). For the landfill development the land (12.6 hectares), next to the landfill, was reserved. Rehabilitation works of Kiskenai, Joskaudai, Puodkaliai, Ankstakiai, Rumsai landfills were organized.

Klaipeda region is equipped with 937 collection sites, to be equipped with an extra 816 ones. By 2020 , bulky waste collection sites (two in Klaipeda region, one - in Kretinga town and Silute district) are to be arranged and the construction of the Klaipeda region landfill section III with the asbestos waste disposal area (Ekokonsultacijos, 2014).

Thus, in order to develop an efficient municipal waste collection, sorting, storage and handling system in the county, it is planned to construct waste collection container sites in all cities and towns of the county, as well as to expand the municipal waste collection system in rural areas (Lietuvos, 2016).

A total of 439 mineral deposits (peat, oil, bulk materials and amber) are in Klaipeda region. Only 6 percent of bulk material resources are already fully exploited. Mining activities are developed by the initiative of private investors. These activities must be conducted in accordance with the principles of sustainable development.

In order to fully evaluate the mineral resources projected demand changes in the region, it is appropriate to prepare the Klaipeda County mineral exploitation feasibility study (with development potential).

The success of the county social and economic development must be based on sustainable and efficient use of sparse local minerals. In order to not affect the natural environment of the county and individual municipalities during the mineral

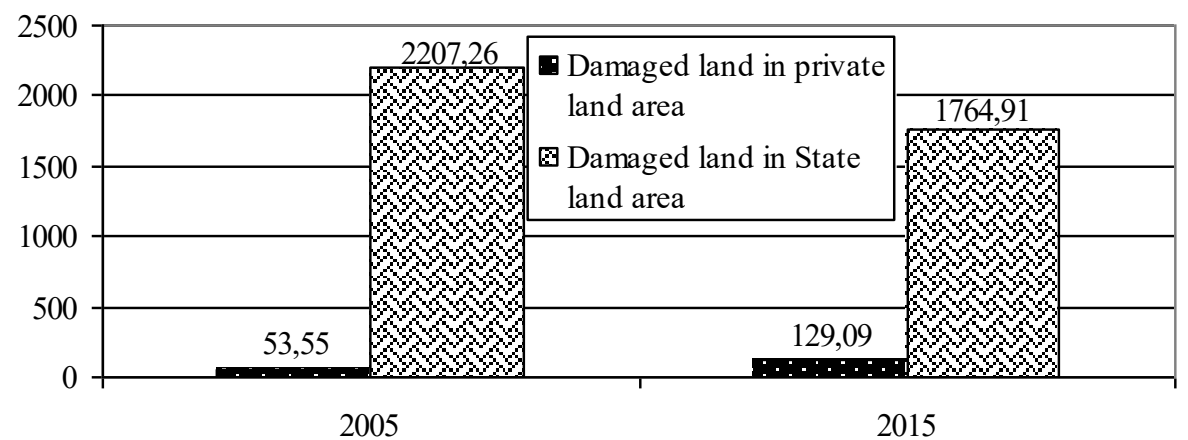

Figure 6. Distribution of the damaged land in Klaipeda County in ha by type of ownership during the years 2005 and 2015, (Compiled by the author of the article). 
exploration, production and exploitation of reservoirs, the development of the mining industry and the business must be guided by the principles of sustainable development.

Mineral (prospected and prognostic) deposits to be used in accordance with the legislation, according to the county market demand. Priority is given to currently existing already prospected and at present prospected, even non-operated resources (Klaipedos, 2016).

\section{Conclusions}

1. Klaipeda county covers an area of 522220.58 ha that makes 7.99 percent of the entire territory of Lithuania. The agricultural lands make up 53.55 percent, forest area 26.89 percent, water bodies 10.43 percent, roads 1.63 percent, other land 3.07 percent of the Klaipeda county. Damage lands covers an area of 2391.06 hectares, or 0.46 percent of the county.

2. Sand deposits are located mainly in Klaipeda County -60 , of which only 8 deposits are used. The least are salts deposits -2 . It was found that, overall in the county, the most used are sand and gravel deposits - 29, not used - sand deposits (52).

3. Klaipeda municipal waste management region comprises 7 municipalities, 39 old dumps were shut down in them, 1 regional non-hazardous waste landfill.

4. In 2005, the analyzed land area of the county was $2,260.81$ hectares or 9.14 percent of all country's damaged lands and 0.43 percent of the Klaipeda County area.

5. During the period between the years 2005 and 2015 the damaged land area in Klaipeda County increased by 130.25 hectares or 5.44 percent. It was influenced by the Klaipeda region landfill section III with the asbestos waste disposal area, the reserved area for construction and mineral production.

6. The largest area of the damaged land in 2015 was fixed in the Klaipeda region municipality, accounting for 15.32 percent of the entire Klaipeda County damaged land. During the period between the years 2005 and 2015 the damaged land area in Klaipeda region decreased by 51.73 hectares or 12.38 percent. In 2005 , the largest area of the damaged land was in Kretinga district. That area decreased by 142.49 hectares or 32.55 percent.

7. The damaged land analysis by type of ownership showed that the damaged land area in private land increased by 75.54 hectares or 58.52 percent. State land area decreased by 442.35 hectares or 20.04 percent.

\section{References}

1. Burger, J. (2008). Environmental management: Integrating ecological evaluation, remediation, restoration, natural resourse damage assessment and long-term stewardship on contaminated lands.

2. Science of the Total Environment. Volume 400, Issuse 1-3. pp. 6 - 9.

3. Ekokonsultacijos. (2014). Klaipedos regiono atliekų tvarkymo $2014-2020 \mathrm{~m}$. planas (Eco-consultation. The Plan of Waste Management of Klaipeda region between the years 2014 and 2020). Klaipèda, 34 p. (in Lithuanian).

4. Klaipeddos regiono 2014 - 2020 metu plètros planas (The Development plan for Klaipeda region in the period of 2014 and 2020). Klaipeda, (2013). 8 p. (in Lithuanian).

5. Klaipèdos regiono atliekų tvarkymo $2014-2020 \mathrm{~m}$. planas (The Waste management plan for Klaipeda's region in the period of 2014 and 2020), Klaipeda, (2016). 101 p. (in Lithuanian).

6. Lietuvos geologijos tarnyba prie Aplinkos ministerijos. Naudingosios iškasenos (Lithuanian Geological Survey under the Ministry of Environment. Minerals.). Retrieved January 15, 2017, from: https://www.lgt. 1t/index.php?option=com_content\&view=article\&id=166\&Itemid=1261\&lang=lt). (in Lithuanian).

7. Lietuvos Respublikos atliekų tvarkymo ịstatymas (2002 07 01, Nr. IX-1004) (The Waste Management Law of the Republic of Lithuania) (2002). Iš Valstybės žinios, Nr. 72-3016. (in Lithuanian).

8. Lietuvos Respublikos Seimo nutarimas „Dèl Lietuvos Respublikos teritorijos bendrojo plano patvirtinimo “ (2002a, Nr. IX-1154), (Resolution of the Seimas of the Republic of Lithuania "On the approval of the General Plan of the territory of the Republic of Lithuania”) (2002). Valstybès žinios, Nr. 110-4852. (in Lithuanian).

9. Lietuvos Respublikos Vyriausybès nutarimas „,Dèl Klaipédos apskrities teritorijos bendrojo (generalinio) plano ptavirtinimo “ (2016, Nr. 769) (The Republic of Lithuania Government Resolution "On the territory of Klaipeda county master (general) plan approval“). (2016). Teisès aktų registras, Nr. 21059. (in Lithuanian).

10. Lietuvos Respublikos Vyriausybės nutarimas „Dèl pažeistos žemès rekultivavimo ir derlingojo dirvožemio sluoksnio išsaugojimo " (1995 08 14, Nr. 116), (The Republic of Lithuania Government Resolution "On the rehabilitation of damaged land and conservation of fertile soil layer”). (1995). Iš Valstybės žinios, Nr. 68-1656). (in Lithuanian). 
11. Lietuvos Respublikos žemės gelmių įstatymas (1995 07 05, Nr. I-1034) (2001 04 25, Nr. IX-243), (The Republic of Lithuania Terrestrial law). (1995). Iš Valstybės žinios, Nr. 63-1582; 2001 b, Nr. 35-1164). (in Lithuanian).

12. Lietuvos Respublikos žemės įstatymas (Lithuanian Republic Law on Land) (1994 04 26, Nr. I-446; 2004 02 21, Nr. IX-1983). (2004). Iš Valstybės žinios, Nr. 28-868. (in Lithuanian).

13. Lietuvos žemès gelmès ir ištekliai (Lithuanian terrestrial and underground resources). Retrieved: January 16, 2017, from: https://smp2014ge.ugdome.1t/mo/9k1_gamtine_geografija/GE_DE_9/teorine_medziaga_2_2. html. (in Lithuanian).

14. Markevicius, N. (2015). Place and role of the Klaipeda region in economy of Lithuania. Procedia Economics and Finance 26, pp. $39-45$.

15. Nacionalinè žemès tarnyba prie Žemès ūkio ministerijos. Lietuvos Respublikos žemès fondas (The National Land Service under the Ministry of Agriculture. Land Fund of the Republic of Lithuania). (2015). Vilnius. 2005 - 2015, p. 44. (in Lithuanian).

16. Sudonienè, V., \& Atkocevičienè, V. (2013). Land Resources Planning and Management. Rural Development. pp. $456-461$.

17. Sumathi, V.R., Natesan, U., \& Sarkar, C. (2008). GIS - based approach for optimized siting of municipal solid waste landfill. Waste Management. Vol. 28 (11), pp. 2146 - 2160.

18. The European Parliament and the Council of the Eurpean Union Directive 2008/98/EB on waste and repealing certain Derectives. (2008 11 19). Official Journal of the European Union (2008 11 22, L 312.28 p.

19. The European Parliament and the Council of the Eurpean Union Directive on the landfill of waste 1999/31/ EC (1999 04 26). Official Journal of the European Communities. (1999 07 16). L182. 19 p.

20. Valstybės kontrolè. (2013). Valstybinio audito ataskaita. regioninių atliekų tvarkymo sistemų veikla (The National Audit Office. State audit report. Regional waste management systems activities) (2013 08 02, Nr. VA-P-20-9-11). Vilnius, 44 p. (in Lithuanian).

21. Valstybės žemės fondo kraštotvarkos ir teritorijų planavimo skyrius. (2012). Klaipėdos apskrities teritorijos bendrasis (generalinis) planas. II - A. Konkretizuoti sprendiniai (Land Management and Territory planning devision of State Fund. General plan of Klaipeda county. Concrete solution). Vilnius, 81 p. (in Lithuanian). 